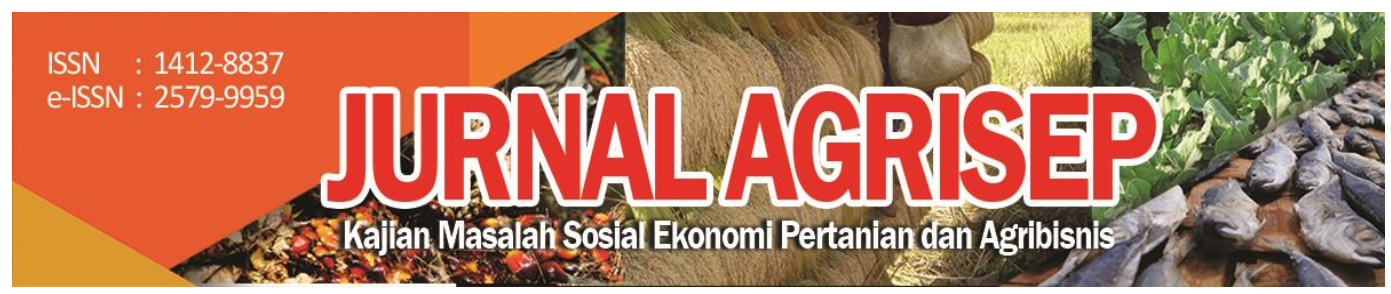

DOI: 10.31186/jagrisep.19.2.289-300

\title{
MODEL PENGELOLAAN PEMBUKAAN LAHAN TANPA BAKAR PADA USAHATANI PADI DIKABUPATEN SANGGAU
}

\section{Management Model For Opening Land Without Fuel On Rice Farming District Of Sanggau}

\author{
Riski Noviyanti 1) \\ 1),2),3) Prodi Agribisnis, Fakultas Pertanian, Universitas Tanjungpura \\ Pontianak \\ Email: riskinoviyanti522@gmail.com
}

\begin{abstract}
The number of hotspots in West Kalimantan in 2018 was 1,075 hotspots. The highest hotspot in West Kalimantan is in Sanggau district which has 200 hotspots on August 15-16, 2018. This study aims to analyze the management model of land clearing without burning carried out by farmers in Sanggau District and determine the factors that have a tendency of farmers to choose the method cultivate land. The sampling method is a method of sampling the probability of 100 respondents calculated using the Slovin formula. Variable characteristics of farmers are age, education, farming experience, farmer knowledge and counseling. The analysis used is binary logistic regression analysis. Data collection was carried out through a questionnaire with direct interview techniques to farmers. The results showed that the factors that have the tendency of farmers to choose how to cultivate land are the age factor of farmers who have a significant value of 0.007 and the experience of farming that has a significant value of 0.034. This informs that the age variable is relatively high and relatively low farming experience has a tendency for farmers to choose how to cultivate land.
\end{abstract}

Keywords : Binary Logistic Regression, Land Fire, Probability Sampling

\section{ABSTRAK}

Jumlah titik api di Kalimantan Barat pada tahun 2018 adalah 1.075 titik api. Hotspot tertinggi di Kalimantan Barat adalah di kabupaten Sanggau yang memiliki 200 hotspot pada 15-16 Agustus 2018. Penelitian ini bertujuan untuk menganalisis 
model pengelolaan pembukaan lahan tanpa pembakaran yang dilakukan oleh petani di Kabupaten Sanggau dan mengetahui faktor-faktor yang memiliki kecenderungan petani untuk memilih cara mengolah lahan. Metode pengambilan sampel adalah metode pengambilan sampel probabilitas 100 responden yang dihitung menggunakan rumus Slovin. Variabel karakteristik petani yaitu umur, pendidikan, pengalaman berusahatani, pengetahuan petani dan penyuluhan. Analisis yang digunakan adalah analisis regresi logistik biner. Pengumpulan data dilakukan melalui kuesioner dengan teknik wawancara langsung kepada petani. Hasil penelitian menunjukkan bahwa faktor-faktor yang memiliki kecenderungan petani untuk memilih cara mengolah lahan adalah faktor umur petani yang memiliki nilai signifikan 0,007 dan pengalaman bertani yang memiliki nilai signifikan 0,034. Ini menginformasikan bahwa variabel usia relatif tinggi dan pengalaman bertani relatif rendah memiliki kecenderungan petani untuk memilih cara mengolah lahan.

Kata Kunci: Kebakaran Lahan, Probabilitas Sampling, Regresi Logistik Binner

\section{PENDAHULUAN}

Kebakaran hutan merupakan salah satu masalah lingkungan yang sering terjadi yang dalam skala besar merupakan salah satu penyebab degradasi hutan dan terbukti menimbulkan kerusakan dan kerugian baik pada aspek ekonomi, ekologi, maupun sosial. Penyebab besarnya kejadian kebakaran hutan di Indonesia bersumber pada lemahnya peraturan perundangan dan penegakan aturan yang ada dan belum optimalnya mekanisme sistem atau kelembagaan yang menangani kebakaran hutan (Tambunan, 2013).

Kalimantan Barat sendiri pembukaan lahan dengan membakar dianggap sebagai penyebab utama kebakaran hutan dan lahan. Kajian kearifan lokal dalam pencegahan kebakaran hutan sangat diperlukan untuk meminimalisir risiko terjadinya kebakaran hutan dan lahan sehingga dapat menjadi acuan yang perlu dikembangkan untuk wilayah yang lebih luas. Sehingga kebijakan tentang penanggulangan kebakaran hutan harus berjalan secara optimal agar dapat mencegah terjadinya kebakaran hutan dan lahan.

Secara tradisional masyarakat adat sudah terbiasa dengan teknik-teknik membakar yang ramah lingkungan yang sudah disesuaikan dengan kondisi alam setempat sehingga tidak menimbulkan dampak yang luas terjadinya kebakaran hutan dan lahan. Pengurangan risiko kebakaran hutan dapat dilakukan dengan mempertimbangkan kearifan lokal dari masyarakat tradisional. Menurut Suhartini (2009), dalam ber- adaptasi dengan lingkungan, masyarakat memperoleh dan mengembangkan suatu kearifan yang berwujud pengetahuan atau ide, norma adat, nilai budaya, aktivitas, dan peralatan sebagai hasil abstraksi mengelola lingkungan khususnya dalam pencegahan kebakaran hutan dan lahan. Seringkali pengetahuan masyarakat adat setempat dijadikan pedoman yang akurat dalam mengembangkan kehidupan di lingkungan pemukimannya. 
Titik api di Kalimantan Barat pada tahun 2018 yaitu 1075 titik api. Titik api tertinggi di Kalimantan Barat adalah pada kabupaten sanggau yang memiliki 200 titik api pada tanggal 15-16 agustus 2018 (BMKG, 2018). Kuat Karhutla di Kalbar terjadi akibat pembakaran serentak. Api sulit ditangani maksimal, karena masyarakat petani membakar di lahan gambut yang tidak begitu luas, namun berada di banyak lokasi dalam waktu secara bersamaan. Bulan Agustus dan September, petani yang menerapkan sistem ladang berpindah melakukan pembukaan lahan pertanian mereka dengan cara dibakar atau yang dikenal dengan istilah adat 'gawai serentak'. Indikasi yang membakar ini adalah masyarakat biasa, karena hotspotnya cenderung naik turun dan tidak stabil, karena mereka membakar hanya dalam hitungan jam, tapi karena di lokasi gambut, sisa asapnya masih banyak (Era Indonesia, 2018).

Masyarakat di Kabupaten Sanggau, Sambas, Ketapang, Kubu Raya dan lainnya memiliki tradisi 'gawai serentak', yaitu kebiasaan persiapan musim tanam dengan membuka lahan dengan cara membakar. Meskipun pemerintah daerah telah melarang, ternyata kebiasaan ini masih dipraktekkan di banyak tempat. Petani lahan kering di Kabupaten Sanggau membakar lahan untuk dijadikan ladang baru. Pembukaan lahan baru dengan cara membakar lahan ini sudah dilakukan turun temurun, setiap awal Agustus yang diprediksi menjadi puncak musim kemarau. Pembukaan lahan dengan cara dibakar ini merupakan tradisi masyarakat untuk mendapatkan pupuk organik yang diperoleh dari hasil sisa pembakaran. Karena terbatasnya pengetahuan masyarakat kabupaten sanggau terhadap model pengelolaan pembukaan lahan tanpa bakar menyebabkan petani di kabupaten sanggau melakukan pembakaran lahan untuk membuka lahan baru. Petani dikabupaten sanggau mau meninggalkan kebiasaan membakar lahan namun mereka tidak memiliki cara lain selain membakar lahan dan biaya yang mereka miliki juga terbatas untuk pengelolaan lahan tanpa membakar.

Penanaman padi di Kalimantan Barat dilakukan rutin setiap tahunnya oleh petani. Sehingga budaya menanam padi setiap tahun nya akan selalu di lakukan baik itu petani subsisten mau pun petani komersil. Apalagi bagi masyarakat dayak di Kalimantan Barat yang memiliki budaya penanaman padi secara serempak setiap tahunnya akan dilakukan karena adanya budaya gawai dayak (gawai padi). Namun penanaman padi yang dilakukan oleh petani di Kalimantan Barat masih tradisional sehingga petani banyak mengesampingkan kearifan lokal lingkungan setempat mengakibatkan pencemaran lingkungan.

Solusinya untuk masyarakat setempat dalam mengatasi titik api yang tinggi di kabupaten sanggau salah satu caranya adalah dengan menerapkan model pengelolan pembukaan lahan tanpa bakar. Dimana model pengelolaan pembukaan lahan tanpa bakar ini dapat mengurangi pencemaran udara dan dapat mengurangi lahan yang terdegradasi. Dengan di terapkan nya model 
tersebut yang dimana telah dilakukan di kabupaten Kapuas hulu yang diberikan oleh PT Paramitra Internusa Pratama (PIP) dan berhasil menghasilkan panen yang jauh lebih besar di banding kan dengan cara membakar. Dilihat dari kebudayaan masyarakat di kabupaten sanggau dan jenis lahan serta varietas yang di usahakan relatif sama maka sistem ini sangat cocok untuk di terapkan di kabupaten sanggau.

\section{METODE PENELITIAN}

Penelitian ini akan dilakukan di Kecamatan Beduai dan di Kecamatan Sekayam Kabupaten Sanggau dengan pertimbangan luas wilayah 43.500 ha dan 84.101 ha dengan kondisi masyarakat yang bermata pencarian utama sebagai petani. Dengan total jumlah penduduk 11.362 jiwa dan 30.256 jiwa dari total jumlah penduduk di kabupaten sanggau 457.701 jiwa.

Penelitian ini bertujuan untuk mendapatkan gambaran mengenai probabilitas faktor karakteristik petani dalam memilih menerapkan model pengelolaan pembukaan lahan tanpa bakar. Metode penelitian yang dipakai dalam penelitian ini adalah penelitian kualitatif deskriptif digunakan untuk mendeskriptifkan model pengelolaan pembukaan lahan tanpa bakar. Menganalisis kecendrungan faktor karakteristik petani dalam memilih menerapkan model pengelolaan pembukaan lahan tanpa bakar digunakan analisis regresi logistik. Penelitian kualitatif adalah proses menjaring informasi dan kondisi yang sebenarnya dalam kehidupan suatu objek yang dihubungkan dengan pemecahan suatu masalah baik dari sudut pandang teoritis maupun praktis (Nawawi, 1993). Penelitian deskriptif yaitu, penelitian yang dilakukan untuk mengetahui nilai variabel mandiri, baik satu variabel atau lebih (independen) tanpa membuat perbandingan, atau menghubungkan dengan variabel yang lain (Sugiyono, 2017).

Metode penelitian ini adalah survei. Sampel dalam penelitian ini ditentukan dengan metode cluster sampling yaitu metode penentuan sampel secara probability sampling dengan pengambilan sample secara bertahap dari wilayah yang sangat luas. Pemilihan sekelompok subjek dalam cluster sampling adalah teknik sampling daerah digunakan untuk menentukan sampel bila objek yang akan diteliti atau sumber data sangat luas, misal penduduk dari suatu negara, provinsi dan kabupaten. Adapun sampel dalam penelitian ini dihitung menggunakan rumus Slovin karena dalam penarikan sampel, jumlahnya harus representative agar hasil penelitian dapat digeneralisasikan dan perhitungannya pun tidak memerlukan tabel jumlah sampel, namun dapat dilakukan dengan rumus dan perhitungan sederhana (Sugiyono, 2017 : Margono, 2004).

Sampel daerah yang digunakan dalam penelitian ini yaitu kabupaten sanggau dimana yang menjadi sampel adalah kecamatan sekayam dan kecamatan beduai yang dimana disetiap kecamatan diambil masing-masing 
satu desa dusun yaitu Desa Sei Tekam dan Desa Kasromego. Dengan perhitungan rumus slovin didapat sampel sebanyak 100 responden.

Regresi logistik digunakan untuk menjelaskan hubungan antara variabel respon yang berupa data dikotomik/biner dengan variabel bebas yang berupa data berskala interval dan atau kategorik (Hosmer dan Lemeshow, 1989). Regresi logistik biner merupakan metode regresi yang peubah respon (Y) hanya terdiri atas dua kategori (dikotomik) yaitu ya dan tidak.

\section{HASIL DAN PEMBAHASAN}

\section{Kondisi Daerah Penelitian}

Wilayah Kabupaten Sanggau terletak pada wilayah dataran tinggi yang berbukit dan berawa-rawa yang dialiri oleh beberapa sungai dengan koordinat antara $109^{\circ} 45^{\prime}$ dan $111^{\circ} 11^{\prime}$ BujurTimur, serta $1^{\circ} 10^{\prime}$ Lintang Utara dan $0^{\circ} 30^{\prime}$ Lintang Selatan, dengan batas-batas sebagai berikut: Sebelah Utara Malaysia Timur (Sarawak), Sebelah Timur Kabupaten Sekadau, Sebelah Selatan Kabupaten Ketapang, Sebelah Barat Kabupaten Landak. Kabupaten Sanggau dengan luas wilayah adalah 12.857,70 km2 ibu kotanya berkedudukan di Kota Sanggau dengan wilayah administrasi meliputi 15 kecamatan dengan 163 desa dan 6 kelurahan (BPS Kabupaten Sanggau Dalam Angka, 2015).

\section{Karakteristik Responden}

Petani padi didominasikan oleh laki-laki dengan presentase 52\% sedangkan perempuan lebih rendah dengan presentase $48 \%$. Hal ini dikarena laki-laki merupakan kepala keluarga yang dimana ketersediaan dan kecukupan konsumsi keluarga akan diperhatikan oleh kepala keluarga karna kepala keluarga merupakan penanggung jawab ketercukupan keluarga sehingga dalam bertani padi khusunya dalam pengolahan lahan sangat diperlukan tenaga laki-laki karena tenaga dan stamina laki-laki lebih kuat di banding perempuan. Umur responden yang paling banyak yaitu berusia antara 36-50 tahun sebanyak 40 responden (40\%). Hal ini menunjukan bahwa petani padi pada usia antara 36-50 tahun lebih aktif bekerja untuk memenuhi kebutuhan keluarganya. Pendidikan responden didominasikan pada tingkat SMP yaitu 41\% lalu SD 33\%, SMA $12 \%$, Tidak Sekolah 11\% dan Sarjana 3\%. Menunjukan tingkat pendidikan responden yang memiliki usaha tani padi sudah tergolong cukup. Pendapatan petani didominasikan sebanyak Rp. 500.000 - Rp. 1.000 .000 dengan presentase $79 \%$ yaitu sebanyak 79 orang dari 100 orang petani. Pendapatan tersebut merupakan pendapatan yang normal atau wajar dalam suatu keluarga, sehingga mereka bisa atau mampu untuk memenuhi kebutuhan keluarganya. Jumlah anak didominasikan sebanyak 2 anak yang dimana presentasenya $40 \%$ yaitu 40 responden dari total responden 
100 orang. Jumlah anak yang dimiliki oleh petani terbilang cukup ideal karna hanya 2 orang anak sesuai dengan anjuran keluarga berencana.

\section{Analisis Regresi Logistik Biner}

\section{Uji Goodnes Of Fit}

Pada penelitian ini tabel Onimbus Test menunjukkan nilai signifikansi sebesar 0,000 < 0,05 yang menunjukkan bahwa penambahan variabel umur, pendidikan, pengalaman berusahatani, pengetahuan petani dan penyuluhan dapat memberikan pengaruh nyata terhadap model, atau dengan kata lain model di nyatakan FIT. nilai P Value Chi-Square sebesar 0,000 dimana < Alpha 0,05 atau nilai Chi-Square hitung 91,108 < dari Chi-Square table 11,070.

\section{Pseudo R Square}

Pada penelitian ini nilai Nagelkerke $R$ Square sebesar 0,885 dan Cox (Sugiyono, 2017) $\mathcal{E}$ Snell $R$ Square sebesar 0,598, yang menunjukkan bahwa kemampuan variabel umur, pendidikan, pengalaman berusahatani, pengetahuan petani dan penyuluhan dalam menjelaskan variabel pemilihan petani tehadap model pengolahan lahan adalah sebesar 0,885 atau $88,5 \%$ dan terdapat $100 \%-88,5 \%=11,5 \%$ faktor lain dari luar model yang menjelaskan variabel pemilihan petani tehadap model pengolahan lahan.

\section{Uji Signifikan Model (Simultan)}

Pada penelitian ini nilai Chi-Square tabel untuk DF 1 (jumlah variabel - 1) pada taraf signifikansi 0,05 adalah sebesar 9,488. Karena nilai Chi Square pada tabel Hosmer And Lemeshow hitung 6,165 < Chi-Square table 9,488 atau Nilai signifikansi sebesar 0,629 >0,05 menunjukkan bahwa tidak ada perbedaan signifikan antara model dengan nilai obsevasiya.

\section{Uji Parsial}

Pada penelitian ini tabel Variabel In The Equation menunjukkan semua variabel Umur mempunyai nilai sig wald 0,007 < 0,05 yang berarti memiliki probabilitas secara signifikan terhadap petani untuk memilih cara mengolah lahan. Pendidikan memiliki nilai sig wald 0,124 >0,05 yang berarti tidak memiliki probabilitas secara parsial yang signifikan terhadap pemilihan petani untuk memilih cara mengolah lahan. Pengalaman berusahatani memiliki nilai sig wald 0,036 < 0,05 yang berarti memiliki probabilitas secara parsial yang signifikan terhadap pemilihan petani untuk memilih cara mengolah lahan. Pengetahuan petani memiliki nilai sig wald 1,000 >0,05 yang berarti tidak memiliki probabilitas secara parsial yang signifikan untuk memilih cara mengolah lahan. Penyuluhan petani memiiki nilai sig wald 0,999 >0,05 yang 
berarti tidak memiliki probabilitas secara parsial yang signifikan untuk memilih cara mengolah lahan.

Persamaan tersebut menjelaskan nilai konstanta sebesar -15,086 yang berarti bahwa $\ln (p / 1-p)=-15,086$ pada saat semua variabel bernilai 0 . nilai tersebut juga mengandung arti bahwa probabilitas memilih menerapkan model pengelolaan pembukaan lahan tanpa bakar adalah sebesar 0,000. Diketahui bahwa probabilitas memilih menerapkan model pengelolaan pembukaan lahan tanpa bakar adalah sebesar 0,00000 .

\section{Variabel Umur}

Variabel umur (X1) memiliki nilai sign wald 0,007 < a $(0,05)$ hal ini menunjukan bahwa variabel umur memiliki probabilitas petani untuk memilih cara mengolah lahan. Karna pola pikir orang yang relatif lebih tinggi lebih mudah untuk memahami model apa yang lebih efektif dan efesien untuk diterapkan.

Besar probabilitas ditunjukkan dengan nilai Exp (B) atau disebut juga Odds Ratio (OR). Variabel umur dengan OR 1,572 maka orang yang berumur lebih tinggi memiliki probabilitas lebih tinggi untuk memilih menerapkan model pengolaan lahan tanpa bakar sebanyak 1,572 kali lipat lebih besar dibandingkan orang yang berumur lebih muda. Nilai B memiliki nilai positif maka semakin tinggi umur semakin tinggi pula probabilitas petani untuk memilih menerapkan model pengelolaan pembukaan lahan tanpa bakar.

Penelitian ini sejalan dengan penelitian Pratiwi (2018) yang menyatakan Variabel umur memiliki probabilitas terhadap adopsi teknologi TSS. Variabel umur memiliki pengaruh secara nyata terhadap adopsi teknologi TSS karna semakin tinggi umur semakin tinggi pula tingkat pemahaman seseorang terhadap inovasi teknologi.

\section{Variabel Tingkat Pendidikan Terakhir}

Variabel tingkat pendidikan terakhir (X2) memiliki nilai sig wald 0,102 > a (0.05) hasil ini menunjukan bahwa tingkat pendidikan tidak memiliki probabilitas petani untuk memilih cara mengolah lahan. Dapat disimpulkan bahwa tinggi rendahnya pendidikan seseorang tidak memiliki memiliki probabilitas petani untuk memilih cara mengolah lahan karna selama petani menempuh pendidikan di bangku sekolah tidak pernah di ajarkan mengenai cara mengolah lahan.

Penelitian ini sejalan dengan penelitian Prabayanti (2010) yang menyatakan tidak adanya pengaruh antar pendidikan formal dengan adopsi biopestisida disebabkan karena petani yang memiliki pendidikan formal tinggi atau rendah samasama berpeluang dalam adopsi inovasi biopestisida. Pendidikan formal tidak berpengaruh terhadap adopsi 
biopestisida karena dalam hal ini bangku pendidikan formal pada umumnya tidak diajarkan mengenai suatu inovasi khusus yang terkait dengan pertanian seperti biopestisida.

\section{Pengalaman berusahatani}

Variabel pengalaman berusahatani (X3) memiliki nilai signifikansi $0,029<\mathrm{a}(0,05)$ hasil ini ini menunjukan bahwa pengalaman berusahatani memiliki probabilitas petani untuk memilih cara mengolah lahan. Karna mengubah pola pikir dan pola usahatani yang memiliki pengalaman berusahatani lebih sedikit lebih mudah di banding kan petani yang memiliki pengalaman berusahatani yang lebih tinggi. Selain hal itu petani yang memiliki pengalaman berusahatani lebih lama memiliki probabilitas untuk menerapkan model pengelolaan pembukaan lahan dengan bakar sehingga sulit untuk mengubah petani untuk menerapkan model pengelolaan pembukaan lahan tanpa bakar.

Variabel pengalaman berusahatani dengan OR 0,519 maka pengalaman berusahatani yang relatif lebih sedikit memiliki probabilitas lebih tinggi untuk memilih menerapkan model pengeloaan pembukaan lahan tanpa bakar sebanyak 0,519 kali lipat lebih besar dibandingkan petani yang memiliki pengalaman berusahatani lebih tinggi.

Penelitian ini sejalan dengan penelitian Sugandi (2012) yang menyatakan pengalaman berusahatani petani berpengaruh nyata terhadap persepsi petani. Semakin lama pengalaman petani semakin paham juga petani terhadap pengambilan sebuah keputusan untuk berusahatani dengan model yang tepat.

\section{Variabel Tingkat Pengetahuan}

Variabel tingkat pengetahuan (X4) memiliki nilai signifikansi 1,000 $>$ a $(0,05)$ hasil ini menunjukkan bahwa tingkat pengetahuan memiliki probabilitas petani untuk memilih cara mengolah lahan karena petani yang tau atau pun tidak tau mengenai model tersebut memiliki jawaban yang sama dan tidak memiliki perbedaan perilaku yang nyata. Tinggi rendahnya tingkat pengetahuan petani mengenai model pengelolaan pembukaan lahan tanpa bakar tidak memiliki probabilitas petani dalam mengolah lahan nya.

Penelitian ini sejalan dengan penelitian Sudrajat (2012) yang menyatakan hasil analisis dengan menggunakan regresi berganda logistik diperoleh hasil tidak terdapat pengaruh nyata antara pengetahuan petani tentang kawasan rawan bencana longsor terhadap perilaku petani. Faktor tingkat pengetahuan petani tentang kawasan rawan bencana longsor tidak menunjukkan adanya pengaruh terhadap perilaku petani dalam mengelola lahan pertanian. 


\section{Variabel Penyuluhan}

Variabel penyuluhan (X5) memiliki nilai signifikansi 0,999 > a $(0,05)$ hasil ini menunjukkan bahwa penyuluhan memiliki probabilitas petani untuk memilih cara mengolah lahan karena petani yang pernah atau pun tidak pernah mengikuti penyuluhan mengenai cara pengolahan lahan tersebut memiliki jawaban yang sama dan tidak memiliki perbedaan perilaku yang nyata. Tinggi rendahnya tingkat penyuluhan petani mengenai model pengelolaan pembukaan lahan tanpa bakar tidak mempengaruhi petani dalam mengolah lahan nya.

Penelitian ini tidak sejalan dengan penelitian Sudrajat (2012) Berdasarkan hasil analisis dengan menggunakan regresi berganda logistik diperoleh hasil yaitu terdapat pengaruh nyata antara penyuluhan petani terhadap perilaku petani. Faktor keikutsertaan petani dalam penyuluhan pertanian memiliki kecenderungan yang bersifat positif terhadap perilaku petani dalam mengelola lahan pertanian.

$$
\begin{aligned}
& \text { Probabilitas }=\frac{(\exp (-15,086+(0,452)-(0,656)))}{1+\exp (-15,086+(0,452)-(0,656)))} \\
& \text { Probabilitas }=1,076
\end{aligned}
$$

Predicted 1,076 $>$ 0,5 maka nilai Predicted Group Membership dari sampel diatas adalah 1 . Dimana 1 adalah kode petani memilih menerapkan model pengelolaan pembukaan lahan tanpa bakar. Jadi jika sampel umur (kode 1) dan pengalaman berusahatani (kode 1) maka prediksinya adalah memilih menerapkan model pengelolaan pembukaan lahan tanpa bakar (kode 1). Jika sampel bersangkutan ternyata faktanya memilih menerapkan model pengelolaan pembukaan lahan dengan bakar (kode 0) maka sampel tersebut keluar dari nilai prediksi. Besarnya perbedaan atau yang disebut dengan Residual $=$ Predicted Group Membership - Predicted. Pada kasus diatas dimana petani yang umur tinggi dan pengalaman berusahatani yang relatif rendah faktanya memilih menerapkan model pengelolaan pembukaan lahan dengan bakar, maka Residual $=0-1,076=-1,076$. 


\section{SIMPULAN DAN SARAN}

\section{Simpulan}

Hasil penelitian yang dilakukan mengenai perilaku petani dalam menerapkan model pengelolaan pembukaan lahan tanpa bakar di Kabupaten Sangga, maka dapat disimpulkan bahwa:

1. Model yang paling efisien menurut responden adalah model pengelolaan pembukaan lahan dengan bakar karena dari tingkat produksi nya tinggi, kemudahan dalam penerapannya tinggi dan biaya yang digunakan dalam penerapannya rendah hingga mengakibatkan probabilitas kecendrungan petani lebih tinggi untuk menerapkan model pengelolaan pembukaan lahan dengan bakar. Jumlah petani yang menerapkan model pengelolaan pembukaan lahan tanpa bakar adalah 25 responden dari total 100 responden artinya $25 \%$ responden menerapkan model tersebut namun 75 responden dari total 100 responden artinya $75 \%$ responden menerapkan model pengelolaan pembukaan lahan dengan bakar.

2. Berdasarkan analisis regresi logistik ada dua variabel yang signifikan dan berpengaruh nyata terhadap variabel dependen yaitu variabel umur dan pengalaman berusahatani memiliki kecendrungan terhadap model pengelolaan pembukaan lahan tanpa bakar. Semakin tinggi umur seseorang semakin cenderung seseorang untuk menerapkan model usahatani padi dengan pengolahan lahan tanpa bakar karna kemampuan seseorang untuk berfikir untuk keberlanjutan lingkungan dapat di pahami oleh petani yang berusia relatif tinggi. Begitu pula pengalaman berusahatani semakin sedikit pengalaman berusahatani semakin besar kecenderungan petani menerapkan model usahatani padi dengan pengolahan lahan tanpa bakar karna ketergantungan terhadap model membakar yang diwarisi secara turun temurun relatif belum lama dilaksanakan sehingga mengubah pola pikir petani menjadi lebih mudah.

\section{Saran}

1. Pembentukan kelompok tani khususnya kelompok tani dalam menerapkan model pengelolaan pembukaan lahan tanpa bakar sangat penting untuk diterapkan agar pengetahuan petani terhadap adanya model pengelolaan pembukaan lahan tanpa bakar diketahui oleh petani sehingga petani mampu untuk menerapkan model tersebut.

2. Pemerintah memberikan penyuluhan secara tepat kepada petani yang berusia tua dan yang bertani khusus nya berladang dengan pengalaman yang relatif rendah agar pola pikir masyarakat dapat diubah hingga dapat merubah kebiasaan masyarakat dari berusahatani dengan cara membakar menjadi berusahatani dengan model pengelolaan pembukaan lahan tanpa bakar. 


\section{DAFTAR PUSTAKA}

Abidin, A. 2016. Pendapatan Dan Faktor Yang Mempengaruhi Pemilihan Usahatani Padi Organik Di Desa Sundawenang,Tasikmalaya. skripsi, 45.

Basuki, A. T. (-). Bahan Ajar Ekonometrika. Universitas Muhammadiyah Yogyakarta, 23.

BMKG. 2018, Agustus 20. Jumlah Hotspot Dikalimantan Barat. Retrieved Mei 25, 2019, from BMKG

https:// pontianak.tribunnews.com/2018/08/20/update-terbaru-jumlahhotspot-di-kalbar-ada-peningkatan

BPS. 2015. Sanggau Dalam Angka. Sanggau: Badan Pusat Statistik (BPS) Sanggau.

Era Indonesia. 2018, Agustus 20. Titik Api Dikalimantan Barat. Retrieved Mei 25, 2019, from Era Indonesia : https://www.era.id/read/p4U0pxmengapa-titik-api-di-kalimantan-barat-begitu-banyak

Handayani, C. P. Kasimin, S. Fajri. 2019. Analisis Faktor-Faktor Yang Mempengaruhi Tingkat Partisipasi Dan Keberhasilan Program Asuransi Usaha Tani Padi (Autp) Di Kabupaten Aceh Besar. Jurnal AGRIFO, 4(1), 11-12.

Harlan, J. 2018. Analisis Regresi logistik. Depok: Gunadarma.

Hayati, E. 2002. Analisis Regresi Logistik Untuk Mengetahui Faktor - Faktor Yang Mempengaruhi Frekuensi Kedatangan Pelanggan Di Pusat Perbelanjaan " $X$ " . Journal UNISLA, 3-5.

Hidayat, A. 2015, februari 25. Interprestasi Regresi Logistik dengan SPSS. Retrieved januari 25, 2020, from Statistikian : https://www.statistikian.com/2015/02/interprestasi-regresi-logistikdengan-spss.html

Lemeshow, David W. Hosmer dan Stanley. 2000. Applied Logistic Regression. Canada : Simultaneously.

Margono. 2004. Metodologi Penelitian Pendidikan. Jakarta: PT Rineka Cipta

Nawawi, H. 1993. Metode Penelitian Sosial. Yogyakarta : Gajah Mada University Press.

Pamungkas, E. T. 2017. Metode Regresi Logistik Biner Pada Faktor Yang Mempengaruhi Kesembuhan Pasien Penderita Demam Berdarah Dengue Di RSUD Dr. Iskak Kabupaten Tulung Agung. Skripsi, 53.

Sholeh, A M. 2017. Model Regresi Logistik. -, 10.

Sugiyono. 2017. Statistika Untuk Penelitian. Bandung: ALFABETA

Tambunan, L. S. Fransisxo G. S. 2013. Kearifan Lokal Masyarakat Adat dalam Pencegahan Kebakaran Hutan dan Lahan (Studi Kasus Masyarakat Adat Kasepuhan Ciptagelar Desa Sirnaresmi, Kecamatan Cisolok, Kabupaten Sukabumi Propinsi Jawa Barat). Silvikultur Tropika, 1. 
Varamita, A. 2017. Analisis Regresi Logistik Dan Aplikasinya Pada Penyakit Anemia Untuk Ibu Hamil Di Rskd Ibu Dan Anak Siti Fatimah Makassar .Skripsi, 69-70 